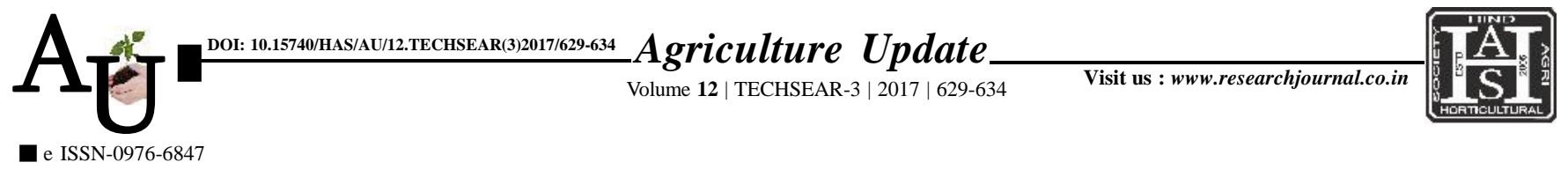

\title{
Research автісlе: Microbial and physico-chemical characteristics of street vended fruit juices
}

\section{P. JAYAMMA, R. RAVEENDRA REDDY, R. ARUNA AND U. SRINEETHA}

Article Chronicle:

Received :

10.07.2017;

Accepted :

25.07.2017

KeY WoRDS :

Fruit juices, $\mathrm{pH}$,

Titrable acidity, TSS,

Colony forming units
SUMMARY : Street vended fruit juices are on high demand because of their nutritive value and mineral and vitamin content but the concern on food safety is very high. This study is aimed to detect different food borne micro-organisms along with Physico-chemical characteristics of freshly prepared street vended fruit juices (sapota, pineapple, grape, mixed fruit juices). A total of 12 juice samples from three different stalls of pulivendula were collected and examined for their physico-chemical properties and for their microbiological quality. Physico-chemical properties of fruit juices include $\mathrm{pH}$, Titrable acidity and TSS. The $\mathrm{pH}$ of sapota juice (7.26) is high when compared to other fruit juices. The titrable acidity was high for grape juice (0.556) and the TSS of sapota juice (20.3) is high. Microbiological analysis includes the isolation and identification of bacteria. The total colony forming units was found high in mixed fruit juices on an average of $8.5 \times 10^{6} \mathrm{cfu} / \mathrm{ml}$ whereas E.coli count was found high in grape with $1.5 \times 10^{4} \mathrm{cfu} / \mathrm{ml}$ and pineapple juices with $1.0 \times 10^{6} \mathrm{cfu} / \mathrm{ml}$ and Staphylococcus was found high in sapota juice with $1.9 \times 10^{4} \mathrm{cfu} / \mathrm{ml}$. Isolated bacteria were identified by using biochemical tests and gram straining.

How to cite this article : Jayamma, P., Reddy, R. Raveendra, Aruna, R. and Srineetha, U. (2017). Microbial and physico-chemical characteristics of street vended fruit juices. Agric. Update, 12(TECHSEAR-3) : 629-634; DOI: 10.15740/HAS/AU/12.TECHSEAR(3)2017/629-634.
Author for correspondence :

\section{P.JAYAMMA}

Department of Food

Safety and Quality

Assurance, College of

Food Science and

Technology,

Pulivendula, KADAPA

(A.P.) INDIA

Email : palurijaya@

gmail.com

See end of the article for

authors' affiliations 